\title{
ANALISIS DETERMINAN PRODUKSI JAGUNG (Studi Kasus: Desa Lenteng Barat Kecamatan Lenteng Kabupaten Sumenep)
}

\author{
AMIR HAMZAH \\ Dosen Fakultas Pertanian Universitas Wiraraja \\ email : amirhamzah@wiraraja.ac.id
}

\begin{abstract}
ABSTRAK
Jagung merupakan komoditas pangan, pakan, dan sumber energi yang terbaharukan. Beragam manfaat dari komoditas jagung, menyebabkan tren permintaan komoditas ini selalu meningkat dari tahun ke tahun. Peningkatan permintaan jagung khususnya di wilayah Kabupaten Sumenep belum diimbangi dengan jumlah produksi yang dihasilkan, sehingga kekurangan permintaan jagung selalu dipenuhi dengan cara impor. Kabupaten Sumenep merupakan daerah penghasil jagung yang potensial, namun tingkat produktifitasnya masih jauh dari kondisi rata-rata di Jawa Timur. Penelitian ini bertujuan untuk menganalisis determinan produksi jagung di Kabupaten Sumenep khususnya di Desa Lenteng Barat Kecamatan Lenteng Kabupaten Sumenep. Metode penentuan sample dilakukan dengan cara Multistage sampling, dengan jumlah sebanyak 120 orang. Metode analisis data yang dipergunakan adalah fungsi produksi translog. Hasil penelitian menunjukkan bahwa analisis determinan dalam produksi usaha tani jagung di Desa Lenteng Barat Kecamatan Lenteng Kabupaten Sumenep adalah variable modal, luas lahan dan tenaga kerja secara positif dan signifikan berpengaruh terhadap produksi jagung di Desa Lenteng Barat Kecamatan Lenteng Kabupaten Sumenep.
\end{abstract}

Kata Kunci : Produksi Jagung, Modal, Luas Lahan dan Tenaga Kerja.

A.

\section{B. PENDAHULUAN}

Sektor pertanian merupakan sektor yang mempunyai peranan strategis dalam struktur pembangunan perekonomian nasional. Sektor ini merupakan sektor yang tidak mendapatkan perhatian secara serius dari pemerintah dalam pembangunan bangsa. Mulai dari proteksi, kredit hingga kebijakan lain tidak satu pun yang menguntungkan bagi sector ini. Program-program pembangunan pertanian yang tidak terarah tujuannya bahkan semakin menjerumuskan sektor ini pada kehancuran. Meski demikian sektor ini merupakan sektor yang sangat banyak menampung luapan tenaga kerja dan sebagian besar penduduk kita tergantung padanya.

Perjalanan pembangunan pertanian Indonesia hingga saat ini masih belum dapat menunjukkan hasil yang maksimal jika dilihat dari tingkat kesejahteraan petani dan kontribusinya pada pendapatan nasional. Pembangunan pertanian di Indonesia dianggap penting dari keseluruhan pembangunan nasional. Ada beberapa hal yang mendasari mengapa pembangunan pertanian di Indonesia mempunyai peranan penting, antara lain: potensi Sumber Daya Alam yang besar dan beragam, pangsa terhadap pendapatan nasional yang cukup besar, besarnya pangsa terhadap ekspor nasional, besarnya penduduk Indonesia yang menggantungkan hidupnya pada sector ini, perannya dalam penyediaan pangan masyarakat dan menjadi basis pertumbuhan di pedesaan.

Pembangunan pertanian di masa yang akan datang tidak hanya dihadapkan untuk memecahkan masalah-masalah yang 
ada, namun juga dihadapkan pula pada tantangan untuk menghadapi perubahan tatanan politik di Indonesia yang mengarah pada era demokratisasi yakni tuntutan otonomi daerah dan pemberdayaan petani. Disamping itu, dihadapkan pula pada tantangan untuk mengantisipasi perubahan tatanan dunia yang mengarah pada globalisasi dunia. Oleh karena itu, pembangunan pertanian di Indonesia tidak saja dituntut untuk menghasilkan produk-produk pertanian yang berdaya saing tinggi namun juga mampu mengembangkan pertumbuhan daerah serta pemberdayaan masyarakat. Ketiga tantangan tersebut menjadi sebuah kerja keras bagi kita semua apabila menginginkan pertanian kita dapat menjadi pendorong peningkatan kesejahteraan masyarakat dan dapat menjadi motor penggerak pembangunan bangsa.

Tanaman jagung sebagai usaha tani yang pengusahaannya dilakukan secara intensif oleh petani untuk mendapatkan hasil maksimal. Namun demikian masih banyak kendala- kendala yang dihadapi petani. Persoalan-persoalan dalam ekonomi pertanian tersebut antara lain: jarak waktu yang lama antara pengeluaran dan penerimaan pendapatan dalam pertanian, karena pendapatan yang diterima petani hanya pada setiap musim panen saja, padahal pengeluaran harus dikeluarkan setiap hari. Pembiayaan pertanian juga menjadi kendala melaratnya petani dan terlibat kepada hutang. Tekanan penduduk dan pertanian, dimana pertumbuhan penduduk tidak sebanding dengan jumlah produksi tani.

Permasalahan lain dari pertanian itu sendiri, menyangkut penentu produktivitas di sektor pertanian, antara lain: pertama faktor eksternal seperti musim kemarau yang menghambat produktivitas pertanian. Faktor kedua adalah penyusutan luas lahan pertanian yang diakibatkan adanya industrialisasi dan urbanisasi. Selanjutnya terbatasnya pemanfaatan teknologi dan rendahnya kualitas Sumber daya manusia juga menjadi penentu produktivitas pertanian.

Begitu juga dengan permasalahan yang dihadapi petani jagung di Desa Lenteng
Barat Kecamatan Lenteng Kabupaten Sumenep dengan geografis dataran tinggi. Kendala yang dihadapi para petani jagung di Desa Lenteng Barat Kecamatan Lenteng Kabupaten Sumenep adalah rendahnya harga jual jagung di pasar, sementara disatu sisi harga pupuk semakin melonjak, sementara subsidi yang diberikan pemerintah tidak dapat sampai kepada para petani karena para petani di Desa Lenteng Barat Kecamatan Lenteng masih harus membayar harga seperti biasanya. Selain itu, sebagian besar para petani jagung di Desa Lenteng Barat ini masih menanam jagung menggunakan tanah sewa dan tanah garapan.

\section{KAJIAN TEORITIS Teori Produksi}

Produksi merupakan keterkaitan antara faktor-faktor produksi dan capaian tingkat produksi yang dihasilkan, dimana faktor produksi sering disebut dengan istilah input dan jumlah produksi yang disebut dengan output. Tujuan perusahaan dalam memproduksi adalah mengubah masukan menjadi keluaran, yang dapat diformulasikan dalam fungsi produksi sebagai berikut :

$$
\mathrm{Q}=\mathrm{f}(\mathrm{K}, \mathrm{L})
$$

Dimana Q adalah keluaran suatu barang tertentu selama satu periode, $\mathrm{K}$ adalah mesin (modal) yang digunakan selama periode itu, L adalah jam kerja masukan tenaga kerja (Joko Triyanto, $2016: 14$ )

Dalam bidang pertanian, produksi fisik dihasilkan oleh bekerja beberapa factor produksi sekaligus, antara lain tanah, benih, pupuk, obat, hama dan tenaga kerja. Seorang produsen yang rasionil tentunya akan mengkombinasikan faktor-faktor produksi sedemikian rupa untuk mencapai usaha tani yang efisien, dan tidak akan menambah input kalau tambahan output yang dihasilkannya tidak menguntungkan (Zulmi, 2017 : 39).

Table 1

Pengaruh Pertambahan Tenaga Kerja Pada

Tingkat Produksi Total Suatu Produk Pertanian 


\begin{tabular}{|c|c|c|c|c|}
\hline $\begin{array}{c}\text { Tanah } \\
\text { (Ha) }\end{array}$ & $\begin{array}{c}\text { T. Kerja } \\
\text { (Orang) }\end{array}$ & $\begin{array}{c}\text { Produksi } \\
\text { Total } \\
\text { (Kuint/Ha) }\end{array}$ & $\begin{array}{c}\text { Produksi } \\
\text { rata-rata } \\
\text { (Kuint/Ha) }\end{array}$ & $\begin{array}{c}\text { Produksi } \\
\text { Marginal } \\
\text { (Kuint/Ha) }\end{array}$ \\
\hline 1 & 1 & 10 & 10 & - \\
1 & 2 & 30 & 15 & 20 \\
1 & 3 & 60 & 20 & 30 \\
1 & 4 & 88 & 22 & 28 \\
1 & 5 & 105 & 21 & 17 \\
1 & 6 & 114 & 19 & 9 \\
1 & 7 & 119 & 17 & 5 \\
1 & 8 & 119 & \pm 15 & - \\
1 & 9 & 110 & \pm 12 & -9 \\
1 & 10 & 70 & 7 & -40 \\
\hline
\end{tabular}

(Sumber : Zulmi, $2017: 40$ )

Dari table 1 di atas dapat diketahui tentang berlakunya "Hukum hasil lebih yang makin berkurang" pada pertambahan input / faktor tenaga kerja sampai dengan 3 orang peningkatan pertambahan produk masih berlangsung seimbang, sejak pertambahan tenaga kerja menjadi 4 orang tambahan produk mulai tidak seimbang makin lama makin turun, bahkan pada pertambahan tenaga kerja menjadi 9 dan 10 orang, dampak kepada hasil produk semakin sulit diraih bahkan mengalami pengurangan atau kemunduran yang dicapainya, sehingga kalau dibandingkan dengan produksi rata-rata ketika tenaga kerjanya 1 orang adalah jauh lebih rendah. Produksi total optimal yaitu ketika produksi memakain tenaga kerja 5 orang. Selanjutnya perhatikan kolom Produksi Total, Produksi Rata-Rata dan Produksi Marginal.

\section{Modal}

Produksi dan biaya produksi bagaikan keeping mata uang logam berisi dua. Jadi produksi berbicara tentang nilai fisik penggunaan factor produksi, biaya mengukurnya dengan nilai uang. Dalam perekonomian yang sudah modern, dimana peranan uang amat penting, maka ukuran efisiensi yang paling baik (walaupun bukan paling lengkap) adalah uang. Sesuatu yang efisien secara teknis, belum tentu secara financial dan ekonomi menguntungkan.
Memproduksi jagung yang efisiensi secara teknis (kualitas pengolahan tanah bagus, tepat waktu dan menguntungkan sedikit tenaga kerja) dapat dicapai dengan menggunakan peralatan pertanian modern (traktor, alat semprot hama mekanis dan lainlain). Tetapi biaya per unit baru akan menjadi murah jika skala produksinya minimal 200 hektar. Padahal kemampuan keuangan petani hanya untuk 2-5 hektar. Untuk skala produksi sekecil itu penggunaan peralatan pertanian modern walaupun efisien secara teknis menimbulkan biaya produksi per kilogram jagung yang sangat tinggi. Petani lebih memilih teknis produksi dengan peralatan sederhana. (Prathama, 2018 : 117).

Dalam kegiatan proses produksi pertanian, maka modal dibedakan menjadi dua macam, yaitu modal tidak bergerak (biasanya disebut dengan modal tidak tetap atau modal variabel). Perbedaan tersebut disebabkan karena ciri yang dimiliki oleh modal tersebut. Faktor produksi seperti tanah, bangunan dan mesin-mesin sering dimasukan dalam katagori modal tetap. Dengan demikian modal tetap dapat didefinisikan sebagai biaya yang dikeluarkan dalam proses produksi yang tidak habis dalam sekali proses produksi. Peristiwa ini terjadi dalam waktu yang relatif pendek (short term) dan tidak berlaku untuk jangka panjang (long term).

\section{Tenaga Kerja Pertanian}

Dalam dunia usaha Pertanian terdapat beberapa faktor produksi. Salah satunya Faktor Tenaga Kerja. Tenaga kerja 
merupakan faktor penting dalam produktivitas pertanian. Pada awalnya, penggunaan tenaga kerja dalam pengolahan lahan pertanian masih dilakukan oleh orang perorangan (keluarga inti), namun pada perkembangan selanjutnya pemilik lahan pertanian akan menerima bantuan dari tetangga dikarenakan tenaga kerja yang berasal dari keluarga tidak cukup untuk mengatasi masalah kekurangan tenaga kerja sedangkan lahan yang harus dikerjakan luas. Dengan imbalannya pada saat tetangga membutuhkan bantuan untuk lahan miliknya, mereka akan saling membantu. (Riberu, 2017)

\section{Luas Lahan}

Luas penguasaan lahan pertanian meruapakan sesuatu yang sangat penting dalam proses produksi atau usaha tani dan usaha pertanian. Dalam usaha tani misalkan pemilikan atau penguasaan lahan yang sempit sudah pasti kurang dibandingkan lahan yang luas. Semakin sempit lahan usaha, semakin tidak efisien usaha tani yang dilakukan kecuali bila usaha tani dijalankan dengan tertib. Luas pemilikan atau penguasaan berhubungan dengan efisiensi usaha tani. Penggunaan masukan akan semakin efisien bila luas lahan yang dikuasai semakin besar.

\section{METODEOLOGI PENELITIAN}

\section{Defenisi Operasional Variabel}

Sesuai dengan variabel-variabel yang diamati, maka definisi operasional dapat dijelaskan sebagai berikut:

1. Produksi Jagung adalah jumlah produksi jagung yang dihasilkan oleh petani di Desa Lenteng Barat Kecamatan Lenteng Kabupaten Sumenep

2. Modal adalah barang atau uang yang bersama-sama dengan faktor produksi lainnya menghasilkan barang-barang baru, yaitu produksi pertanian dalam satuan Rupiah perpanen (yakni seluruh biaya selama proses memproduksi jagung)

3. Luas Lahan adalah total luas lahan yang digunakan petani untuk di tanami jagung dalam satuan area per panen, luas lahan yang di usahakan petani di daerah penelitian yakni 0,5 - $1 \mathrm{Ha}$ ke atas.

4. Tenaga Kerja adalah jumlah tenaga kerja (orang) yang digunakan dalam suatu kegiatan produksi untuk menyelesaikan pekerjaan dalam usahatani, dinyatakan dalam (Jumlah Orang Kerja)

\section{Teknik Analisis Data}

Model analisis yang akan digunakan dalam penelitian ini adalah model analisis regresi linear berganda. Analisis regresi digunakan untuk mengetahui pengaruh Modal, Luas lahan, Tenaga Kerja, terhadap jumlah produksi padi di Kec. Lenteng Kab. Deli Serdang yang dinyatakan dalam bentuk fungsi sebagai berikut:

$\mathrm{Y}=\mathrm{f}\left(\mathrm{X}_{1}, \mathrm{X}_{2}, \mathrm{X}_{3},\right)$

Atau dirumuskan dalam bentuk fungsi CobbDougs, menjadi:

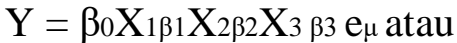

$\mathrm{Y}=\mathrm{A} \mathrm{L} \alpha \mathrm{K}_{\beta}$

Akan lebih mempermudah penyelesaian dengan menggunakan bentuk logaritma natural $(\ln )$, yaitu:

$\operatorname{Ln} Y=\operatorname{Ln} \beta_{0}+\beta_{1} \operatorname{Ln} X_{1}+\beta_{2} \operatorname{Ln} X_{2}+\beta_{3} \operatorname{Ln} X_{3}$

$+\mu$

Dimana :

Y

$\mathrm{X} 1 \quad=$ Modal

X2 $=$ Lahan / Luas Lahan

$\mathrm{X} 3 \quad=$ Tenaga Kerja

$\beta 0 \quad=$ Konstanta

$\beta 1, \beta 2, \beta 3, \quad=$ Koefisien regresi

$\mu=$ Error term

\section{E. PEMBAHASAN}

\section{Produksi Jagung di Kec.Lenteng}

Berdasarkan gambar 2 bahwa hasil produksi pertanian 1 orang dengan hasil produksi 6 ton, 26 orang dengan hasil produksi 7 ton, 4 orang dengan hasil produksi 8 ton, 2 orang dengan hasil produksi 9 ton, 4 orang dengan hasil produksi 12 ton, 2 orang dengan hasil produksi 13 ton, 15 orang dengan hasil produksi 14 ton, 6 orang dengan hasil 21 ton. 


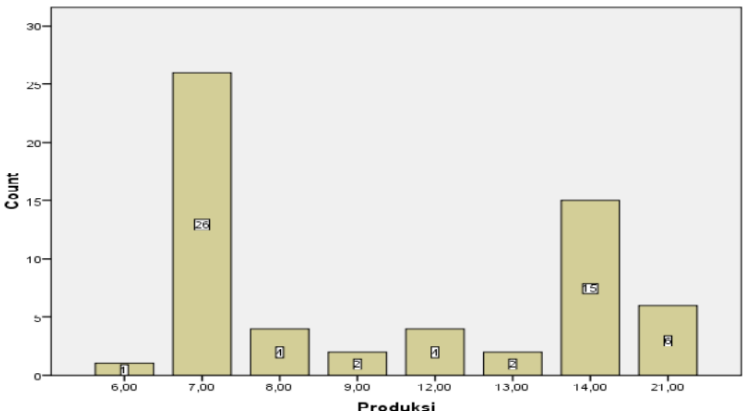

\section{Produksi Jagung di Desa Lenteng Barat}

\section{Uji Regresi}

Anlisis Uji regresi merupakan analisis untuk melihat ketergantungan variabel dependen (terikat) dengan satu atau lebih variabel independen (bebas).hasil analisis regresi adalah berupa koefisien untuk masingmasing variabel independen diperoleh dengan cara memprediksi nilai variabel dependen dengan suatu persamaan.Persamaan regresi linear berganda apda penelitian ini adalah sebagai berikut:

$\operatorname{Ln} Y=\operatorname{Ln} \beta_{0}+\beta_{1} \operatorname{Ln} X_{1}+\beta_{2} \operatorname{Ln} X_{2}+\beta_{3} \operatorname{Ln} X_{3}$ $+\mu$

\section{Dimana :}

$\mathrm{Y}=$ Produksi jagung

$\mathrm{X} 1=$ Modal

X2 $=$ Lahan / Luas Lahan

X3 $=$ Tenaga Kerja

$\beta 0=$ Konstanta

$\beta 1, \beta 2, \beta 3, \quad=$ Koefisien Regresi

$\mu \quad=$ Error term

Setelah dilakukan uji regresi maka diperoleh hasil output SPSS tabel coeffisients, Anova dan tabel Model Summmary sebagai berikut:

Tabel 2

Uji Regresi

\begin{tabular}{|l|l|r|r|r|r|c|}
\hline \multicolumn{7}{|c|}{ Coefficients } \\
\hline \multirow{2}{*}{\multicolumn{2}{|c|}{}} & \multicolumn{2}{|c|}{$\begin{array}{c}\text { Unstandardized } \\
\text { Coefficients }\end{array}$} & $\begin{array}{c}\text { Standardized } \\
\text { Coefficients }\end{array}$ & & \\
\cline { 2 - 7 } & B & $\begin{array}{c}\text { Std. } \\
\text { Error }\end{array}$ & Beta & $\mathrm{t}$ & Sig. \\
\hline \multirow{2}{*}{1} & (Constant) & .593 & .271 & & 2.186 & .033 \\
\cline { 2 - 7 } & $\mathrm{X} 1$ & .586 & .098 & .628 & 5.964 & .000 \\
\hline
\end{tabular}

\begin{tabular}{|l|l|l|l|l|l|l|}
\hline $\mathrm{X} 2$ & .179 & .085 & .207 & 2.100 & .040 \\
\hline $\mathrm{X} 3$ & .287 & .143 & .148 & 2.016 & .049 \\
\hline
\end{tabular}

a. Dependent Variable : Y (Inproduksi)

Sumber: Hasil Output SPSS versi 24 dari Pengolahan

Data Primer (2022)

Maka dari hasil output SPSS diatas maka diperoleh persamaan regresi linear berganda sebagai berikut:

$\mathrm{Y}=0,593+0,586 \mathrm{X}_{1}+0,179 \mathrm{X}_{2}+0,287 \mathrm{X}_{3}+\mathrm{e}$ Interpretasi dari persamaan regresi linear berganda adalah:

1) Konstanta $(\alpha)$ mempunyai regresi sebesar 0,593, artinya jika variabel Modal ( $\left.\mathrm{X}_{1}\right)$, Luas Lahan $\left(\mathrm{X}_{2}\right)$ dan Tenaga kerja $\left(\mathrm{X}_{3}\right)$ di anggap nol,maka ada kenaikan produksi jagung sebesar 0,593.

2) Modal $\left(\mathrm{X}_{1}\right)$ mempunyai koefisien regresi sebesar 0,586, artinya bahwa setiap kenaikan variabel modal sebesar $1 \%$ ,maka akan terjadi peningkatan produksi jagung sebesar 59,3\%

3) Luas Lahan $\left(\mathrm{X}_{2}\right)$ mempunyai koefisien regresi sebesar 0,179, artinya bahwa setiap kenaikan variabel luas lahan sebesar $1 \%$,maka akan terjadi peningkatan produksi jagung sebesar $17,9 \%$

4) Tenaga kerja $\left(X_{3}\right)$ mempunyai koefisien regresi sebesar 0,287, artinya bahwa setiap kenaikan variabel tenaga kerja sebesar 1\%, maka akan terjadi peningkatan produksi jagung sebesar $28,7 \%$.

\section{Koefisien Determinasi}

Tabel 3

Uji Koefisien Determinasi Model Summary

\begin{tabular}{|l|c|r|c|c|}
\hline Model & $\mathrm{R}$ & $\mathrm{R}$ Square & $\begin{array}{c}\text { Adjusted R } \\
\text { Square }\end{array}$ & $\begin{array}{c}\text { Std. Error of the } \\
\text { Estimate }\end{array}$ \\
\hline 1 & $.918^{\mathrm{a}}$ & .843 & .835 & .15922 \\
\hline $\begin{array}{l}\text { a. Predictors: (Constant), X3, X1, X2 } \\
\text { b. Dependent Variable : Y (Inproduksi) }\end{array}$ \\
\hline
\end{tabular}

Sumber : Hasil Output Spss versi 24 Dari Pengolahan Data Primer (2022)

Berdasarkan output SPSS nilai koefisien korelasi (R) sebesar 0,918 yang 
menunjukkan bahwa derajat hubungan (korelasi) antara variabel independen dengan variabel dependen sebesar 91,8\%. Artinya koefisien modal, luas lahan dan tenaga kerja mempunyai hubungan yang kuat dengan produksi jagung.

Koefisien determinasi yang sudah disesuaikan (Adjusted $R$ Square) sebesar 0,835. Artinya $83,5 \%$ variabel dependen produksi jagung dijelaskan oleh variable independent yaitu Modal, Luas lahan dan tenaga kerja, dan sisanya $16,5 \% \quad(100 \%$ $83,5 \%)$ dijelaskan oleh variabel lain diluar variabel yang digunakan.

\section{Uji Hipotesis secara Parsial (Uji t)}

Hasil hipotesis (Uji t) dilihat pada tabel Coefficientsa. Uji t bertujuan untuk mengetahui besarnya pengaruh masingmasing variabel independen secara individual (parsial) terhadap variabel dependen.

\section{Tabel 2}

Uji Hipotesis secara Parsial

\begin{tabular}{|c|c|c|c|c|c|c|}
\hline \multicolumn{7}{|c|}{ Coefficients } \\
\hline \multirow{2}{*}{\multicolumn{2}{|c|}{ Model }} & \multicolumn{2}{|c|}{$\begin{array}{l}\text { Unstandardized } \\
\text { Coefficients }\end{array}$} & \multirow{2}{*}{$\begin{array}{c}\begin{array}{c}\text { Standardized } \\
\text { Coefficients }\end{array} \\
\text { Beta }\end{array}$} & \multirow[b]{2}{*}{$\mathrm{t}$} & \multirow[b]{2}{*}{ Sig. } \\
\hline & & B & $\begin{array}{l}\text { Std. } \\
\text { Error }\end{array}$ & & & \\
\hline 1 & \begin{tabular}{|l|} 
Con \\
Stant)
\end{tabular} & .593 & .271 & & 2.186 & .033 \\
\hline & $\mathrm{X} 1$ & .566 & .098 & .628 & 5.964 & .000 \\
\hline & $\mathrm{X} 2$ & .179 & .085 & .207 & 2.100 & .040 \\
\hline & X3 & .287 & .143 & .148 & 2.016 & .049 \\
\hline
\end{tabular}

a. Dependent Variable : Y (Inproduksi)

Sumber: Hasil Output SPSS versi 24 dari Pengolahan Data Primer (2022)

Untuk melihat nilai tabel yaitu $\mathrm{df}(\mathrm{n})$ $\mathrm{k}=60-3=57, \alpha 5 \%$. Hasil output menunjukkan hasil:

a. Variabel Modal diperoleh thitung 5,964 > tabel 2,0047 dan tingkat signifikan 0,000 < 0,0005 , maka keputusannya adalah menerima $\mathrm{H}_{a}$ dan $\mathrm{H}_{0}$ ditolak. Hasil ini menunjukkan bahwa modal berpengaruh signifikan terhadap produksi jagung. Hasil menunjukkan hipotesis diterima.

b. Variabel Luas lahan diperoleh thitung 2,100

$>$ tabel 2,0047 dan tingkat signifikan 0,040
$<$ 0,0005, maka keputusannya adalah menerima $\mathrm{H}_{\mathrm{a}}$ dan $\mathrm{H}_{0}$ ditolak. Hasil ini menunjukkan bahwa luas lahan berpengaruh signifikan terhadap produksi jagung. Hasil menunjukkan hipotesis diterima.

c. Variabel Tenaga kerja diperoleh thitung 2,016 > tabel 2,0047 dan tingkat signifikan $0,049<0,0005$, maka keputusannya adalah menerima $\mathrm{H}_{\mathrm{a}}$ dan $\mathrm{H}_{0}$ ditolak. Hasil ini menunjukkan bahwa tenaga kerja berpengaruh signifikan terhadap produksi jagung.

Hasil menunjukkan bahwa hipotesis diterima.

\section{Uji Hipotesis secara Simultan (Uji F)}

Hasil hipotesis ( Uji F) dapat dilihat dari hasil regresi pada tabel ANOVA dari output SPSS. Uji $F$ menunjukan variabel independen secara bersama -sama (simultan) berpengaruh terhadap variabel dependen. Untuk mengetahui analisi uji hipotesi secara simultan dapat dilihat dari tabel output SPSS Di bawah ini:

Tabel 5

\section{Uji Hipotesis secara Simultan (Uji F)} ANOVA $^{b}$

\begin{tabular}{|l|l|r|r|r|c|c|}
\hline \multicolumn{2}{|l|}{} & $\begin{array}{r}\text { Sum of } \\
\text { Squares }\end{array}$ & df & $\begin{array}{c}\text { Mean } \\
\text { Square }\end{array}$ & $F$ & Sig. \\
\hline 1 & Regression & 7.642 & 3 & 2.547 & 100.477 & $.000^{\mathrm{a}}$ \\
\cline { 2 - 7 } & Residual & 1.420 & 56 & .025 & & \\
\cline { 2 - 7 } & Total & 9.061 & 59 & & & \\
\hline
\end{tabular}

a. Predictors: (Constant), X3, X1, X2

b. Dependent Variable: $Y$

Sumber : Hasil Output Spss versi 24 Dari Pengolahan

Data Primer (2022)

Hasil Output SPSS diatas menunjukkan sig $0,000<0,05$, artinya signifikan, Fhitung 100,477 > Ftabel 3,16. Untuk melihat nilai Ftabel yaitu $\operatorname{df}(\mathrm{N} 1)=3-1=2$, $\mathrm{df}(\mathrm{N} 2)=603=57$. Artinya modal, luas lahan, dan tenaga kerja secara simultan/bersamasama berpengaruh signifikan terhadap produksi jagung, maka keputusannya Ho ditolak dan $\mathrm{Ha}$ diterima artinya hipotesis diterima. 


\section{F. KESIMPULAN DAN SARAN Kesimpulan}

Berdasarkan dari hasil penelitian yang telah dilakukan pada variabel Modal, Luas lahan dan Tenaga kerja terhadap produksi jagung di Desa Lenteng Barat Kecamatan Lenteng Kabupaten Sumenep maka dapat disimpulkan bahwa:

1. Variabel modal secara positif berpengaruh terhadap produksi jagung di Kecamatan Lenteng. Semakin besar modal yang dimiliki atau digunakan maka semakin banyak pula hasil produksi jagung yang di hasilkan. Dengan didukung oleh lahan yang dimilki dan kualitas bibit yang digunakan.

2. Variabel luas lahan secara positif berpengaruh terhadap produksi jagung di Desa Lenteng Barat Kecamatan Lenteng. Dikarenakan semakin luas lahan yang dimilki atau digunakan maka semakin banyak pula produksi jagung yang dapat dihasilkan. Luas lahan yang cukup dan didukung oleh kondisi tanah yang subur dan cuaca maka akan dapat meningkatkan hasil produksi jagung.

3. Variabel tenaga kerja secara positif dan signifikan mempengaruhi produksi jagung di Desa Lenteng Barat Kecamatan Lenteng. Artinya semakin lama waktu yang diluangkan untuk mengolah tanaman jagung baik dalam perawatan dan pengawasan maka akan dapat meningkatkan produksi jagung tersebut.

\section{Saran}

Berdasarkan penelitian dan kesimpulan diatas, maka penulis memberikan beberapa saran, sebagai bentuk implementasi dari hasil penelitian ini, sebagai berikut:

1. Modal dipergunakan sebijaksana mungkin demi adanya kelanjutan produksi jagung. Modal tidak hanya digunakan dalam per panen tapi dapat juga digunakan pada musim panen selanjutnya.

2. Untuk Pemerintah Daerah atau pun pihakpihak yang terkait dengan pertanian agar dapat memberikan penyuluhan atau pengarahan kepada para petani jagung dalam rangka meningkatkan produksi. Selain itu perlu dibuat program pengembangan sektor pertanian khususnya jagung, termasuk upaya-upaya peningkatan kemampuan, pemberian modal, ketersediaan pupuk, obat-obatan dan tidak kalah penting adalah perbaikan sarana prasarana jalan karena ini merupakan untuk memudahkan transportasi pengangkutan hasil panen. Dan pemerintah juga perlu melakukan regulasi harga agar dapat mencapai laba maksimum bagi petani.

DAFTAR PUSTAKA

Atalia Sembiring (2013). "Makalah Produksi dan Biaya Jangka Panjang". http://goresankuliahku.blogspot.com/2013/0 5/makalah-produksi-dan biayajangka.html. Diposting Selasa 14 Mei 2013

Bpp (2009), "Kondisi Pertanian di Indonesia Berdasarkan Pandangan Mahasiswa PertanianIndonesia", http://www.facebook.com/topic.php?uid=13 8074680647 \&topic $=13465$, Diakses 17 September 2009.

Badan Pusat Statistik (2013). Kabupaten Deli Serdang dalam Angka 2013. Sumatera Utara.

Heru Purwadio dan Ikhlas Saili (2012). “ Pengendalian Alih Fungsi Lahan Menjadi Perkebunan Kelapa Sawit Kabupaten Siak Riau". Artikel Teknik Perencanaan Wilayah dan Kota Vol. 1, No. 1, (2012)

Joko Triyanto (2006). Analisis Produksi Padi di Jawa Tengah. Pasca Sarjana Universitas Diponogoro Semarang. Tesis (dipublikasikan melalui www.google.com)

Mulyadi Subri (2003). Ekonomi Sumber Daya Manusia. PT. Raja Grafindo Persada. Jakarta.

Pangestu Subagyo M. B. A dan Djarwanto (2005). Statistika Induktif (Edisi 5). BPFE. Yogyakarta.

Philipus Riberu (2011). "Tenaga Kerja dalam Ekonomi Pertanian". http://riberuphilip.blogspot.com/2011/05/te naga-kerja-dalam-ekonomi pertanian. html

Pratama Rahardja dan Mandala Manurung ( 2008). Pengantar Ilmu ekonomi (Mikroekonomi dan Makroekonomi) (Edisi 3). Fakultas Ekonomi Universitas Indonesia. Jakarta.

Rico Phahlevi (2007). Faktor-faktor yang Mempengaruhi Pendapatan Petani Padi Sawah di Kota Padang Panjang. Universitas Negeri Padang. Artikel (dipublikasikan melalui www.google.com)

Sugiyono. 2003. Metode Penelitian Bisnis. Pusat Bahasa Depdiknas. Bandung. 